UDC 378.018 .43

DOI: 10.15587/2706-5448.2021.237455

Article type «Reports on Research Projects»

\section{Andrii Biziuk, Valerii Biziuk, Tatiana Shakurova}

\title{
ANALISYS OF TEACHING ELEMENTS ON TECHNICAL AND MATHEMATICAL DISCIPLINES IN MODERN DISTANCE EDUCATION
}

The object of research is the quality of teaching technical and mathematical disciplines in modern distance education. One of the most problematic areas is communication, dialogue between a teacher and a student, personality problems in the teacher-student dyad, and the effectiveness of feedback. The idea of distance learning, obviously, is that the interaction between teacher and student takes place in a virtual space. The more efficiently this interaction is built by using a variety of techniques, methods, the better a teaching process. Distance teaching is essentially a person-centered form of education. This is a separate modern educational technology that provides a choice for the teacher, the ability to select educational material depending on the information needs of students.

In the course of the study, the main possibilities for improving the effectiveness of feedback between the student and the teacher and the forms of implementing such communication were considered. The organizational and pedagogical conditions for the use of the system of certain elements of distance learning in the process of vocational training have been substantiated. Modern information technologies and innovative teaching methods in training specialists are described. It is proposed to use more actively such elements as an interactive whiteboard, interactive processing of students' statements during a survey, both in the form of tests or a forum, and in the form of a «word cloud». The use of these interactive elements has proven itself in practice.

As a tool for objective assessment of the level of feedback, a comparative analysis of statistical data is proposed, which concerns the distribution of marks at the beginning and at the end of the distance learning course. This data can also be interpreted as an indicator of the quality of teaching. In particular, the analysis of school preparation of students for mastering mathematical disciplines in higher education was carried out. Comparative analysis substantiated, in particular, the need for additional classes for students with poor preparation.

Keywords: distance education, mathematical disciplines, technical disciplines, teaching quality, teacher-student dialogue, feedback.

How to cite

Biziuk, A., Biziuk, V., Shakurova, T. (2021). Analisys of teaching elements on technical and mathematical disciplines in modern distance education Technology Audit and Production Reserves, 4 (2 (60)), 28-32. doi: http://doi.org/10.15587/2706-5448.2021.237455

\section{Introduction}

In recent decades, the scientific and methodological foundations of distance learning have been rapidly developing. Problems on the development of distance education are devoted to works both at the general theoretical and methodological level [1], and in the consideration of certain practical aspects [1-3]. The number of international conferences on Distance Teaching \& Learning is constantly growing $[4,5]$. The problems of combining the depth and fundamentality of education with the modern requirements of rapid changes and increasingly shorter formats for presenting materials are considered. Organizational and managerial schemes for supporting the digital transformation of universities are changing. Under the influence of new digital technologies, the educational system is changing at the global, regional and local levels. It becomes necessary to discuss complex issues of technical support of the process, the creation of new skills for working in the Internet environment (both for teachers and for students), setting up fruitful communication of scientific, educational and socially personal. The use of an increasing variety of possibilities, fundamentally new forms and methods of teaching becomes necessary both in a general context and in individual specific applications.

Distance learning has arisen as a result of the development of computer technology and has found wide application in correspondence education. Distance learning is essentially a person-centered form of learning. This is a separate modern educational technology that makes it possible to choose a teacher, the choice of educational material, depending on the information needs of students [6]. Distance courses replaced students with voluminous textbooks, teaching aids and in a concise form offered the necessary amount of 
information on a specific subject, section, adapted to the specialty. The introduction of distance courses has made it possible to qualitatively improve the educational process, create conditions for continuous study of the subject, and not only during the sessions.

Moreover, distance courses provided an opportunity for the teacher to control the educational process, for example, by intermediate educational tests, questions to the student, and finally, passing exams in a test or other form. By the way, the remote form made it possible for educational institutions to save money on business trips of teachers to the branches of an educational institution, which were quite ramified at that time [7, 8].

The remote form has radically changed with the introduction of quarantine during the Covid-19 pandemic. As shown in [9], so far the situation is favorable for the educational process, since it makes it possible to think outside the box and raise more modern and critical questions. A feature of distance education is that the direct process of transferring knowledge from the teacher to the student is disrupted due to distance and the inability to track the student's reaction. Distance courses created for correspondence courses had to be adapted to full-time courses or new ones had to be created. There were problems of the methodological nature of teaching a particular discipline, in particular mathematics, higher mathematics, applied disciplines [10]. That is, those disciplines that are not limited to the text and it is necessary to operate with formulas, equations, graphs and the like. And it is in this aspect, in this direction, there are a number of problems that require attention to improve, improve the quality of teaching these disciplines.

In distance learning, communication between a student and a teacher occurs in the form of a link. One of the main aspects of the remote methodology is the use of synchronous communication, that is, communication in real time, involves active interaction between the teacher and students. Technically, such communication can be provided with the help of interactive elements of distance learning forums, chats, tests, task-task elements, resources for accumulating and presenting meaningful content, etc. [11].

Own experience of using interactive elements while teaching technical disciplines [12] shows both the correctness of the proposed approach and the need for further improvement and expansion of the tools involved.

This point of view was also expressed by other researchers of modern technologies of distance learning [5], who note that the use of distance technologies has a number of advantages over traditional forms. They also indicate that modern technology trends affect:

- increasing motivation for learning activities;

- provide opportunities for the use of new forms in the educational process, in which students will learn not only to assimilate knowledge, but also to acquire it independently;

- to use the acquired knowledge during the educational process and in everyday activities. Among such trends are cloud technologies, inverted classroom, Big Data, Gamification of education, robotics, augmented reality, and the like.

The quality of distance learning depends on the fulfillment of several key conditions:

- effective feedback from students to the teacher;

- active involvement of students in the learning process;
- use of a flexible assessment system to motivate students, when self-assessment is seen as an additional learning tool;

- ability of students to self-discipline and independent work [13].

Thus, the urgent is the need for a more detailed study of the means that can provide the specified conditions. The object of this research is the quality of teaching technical and mathematical disciplines in modern distance education. Such a study is based on the analysis of modern interactive elements, the experience of using which in the process of teaching technical disciplines, in particular, higher mathematics, allows us to draw certain conclusions.

The aim of research is to analyze the elements of teaching technical and mathematical disciplines in modern distance education. Among such elements, an interactive whiteboard, interactive processing of students' statements during a survey, both in the form of tests or a forum, and in the form of a «word cloud», are considered in the future.

\section{Methods of research}

The paper considers the possibilities of assessing the effectiveness of feedback between a student and a teacher and the forms of implementation of such communication. A comparative analysis of statistical data that can be interpreted as an indicator of the quality of teaching has been carried out. Some of the interactive elements that have proved to be successful in practice are presented.

The quality of teaching mathematics, like other technical disciplines in a higher educational institution, undoubtedly depends on school preparation, that is, on the baggage of knowledge that a student possesses. Let us describe the scope of research in the teaching of mathematics and higher mathematics at the university by analyzing the factors affecting the quality of teaching.

For the study, the results of the autumn semester of the flow of the first year of specialty 141 (Electrical power engineering, electrical engineering and electromechanics) of the O. Beketov National University of Urban Economy in Kharkiv (Ukraine). These data, in comparison with the distribution of the results obtained by the participants, passed the state final certification in mathematics [13, 14]. That is, by the same students, according to the levels of knowledge given in the report of the Ministry of Education and Science of Ukraine on conducting in 2019 an external independent assessment of learning outcomes obtained on the basis of complete general secondary education.

\section{Research results and discussion}

The diagrams in Fig. 1, as expected, confirm the main thesis. A similar diagram is shown for the 2020 graduates (Fig. 2). Compared to the results of external independent evaluation (EIE), the results of the session are slightly better due to the increase in the number of assessments of a sufficient level. It can be assumed due to the better enrollment in the first year, but rather this is a consequence of the fact that students received part of the certification points in a distance form. In particular, when drawing up the current control in a test form, it is more objective to send written responses by e-mail.

The diagrams in Fig. 1, 2 can serve as a control of the objectivity of the assessment of a student's knowledge, 
as an indicator of the quality of teaching mathematics, at least in the first year. On the other hand, the analysis of success reveals students who need additional classes to restore or replenish their knowledge of certain sections of mathematics. In any case, distance courses should contain information on the main sections of mathematics algebra, geometry, trigonometry, vector algebra, as well as tables, formulas, and the like. These figures show the results of external independent assessment in dark gray, and the results of the autumn session of the same contingent of students in light gray.

Training involves the interaction of a teacher and a student. It is the teacher, acting as an interpreter of knowledge, who introduces emotional coloring into the learning process, implements feedback and, if necessary, can correct the student's learning process.

Feedback in the learning process is understood as information about the state of a controlled object - a student, a student at each specific moment of its activity. Feedback is, first of all, a characteristic of the student's state (readiness for classes, mood, attentiveness, its responses to the psychophysiological state, etc.), on the basis of which the teacher chooses teaching tactics, flexibly reacting to changes in the student's state [1, 2, 7].

Feedback is the concept of distance learning from the point of view of the teacher, which for the student is actually an individual form of education, which both sides aspire to and which, of course, is impossible with classroom teaching. Ideally, the student, using the individual form, automatically provides the teacher with feedback through direct communication, activity, creativity.

However, in reality, in reality, in the educational process, the audience is multi-colored. And therefore, it is the teacher who belongs in any way to motivate the student.

Traditionally, feedback is considered as control of the tasks given by the teacher, for which various testing options, current and control tasks, tests and exams, and the like are widely used.

However, it is important to provide feedback in the process of presenting theoretical knowledge from the teacher to the student. In the classroom form of lectures, a question to the audience, discussion and problem lectures (in full or as part of a traditional lecture), discussion of actualized issues, and the like are widely used. By posing a simple question to the audience, the teacher, based on the students' quick reaction, can make a generalizing digression, present the proof in more detail, or omit the material already known to the students, focusing on new aspects. In the case of distance learning, such an urgent reaction is often difficult or completely impossible [7, 8].

Undoubtedly, the choice of methods, methods of teaching a particular discipline depends on the discipline itself. With regard to mathematics, for example, in contrast to

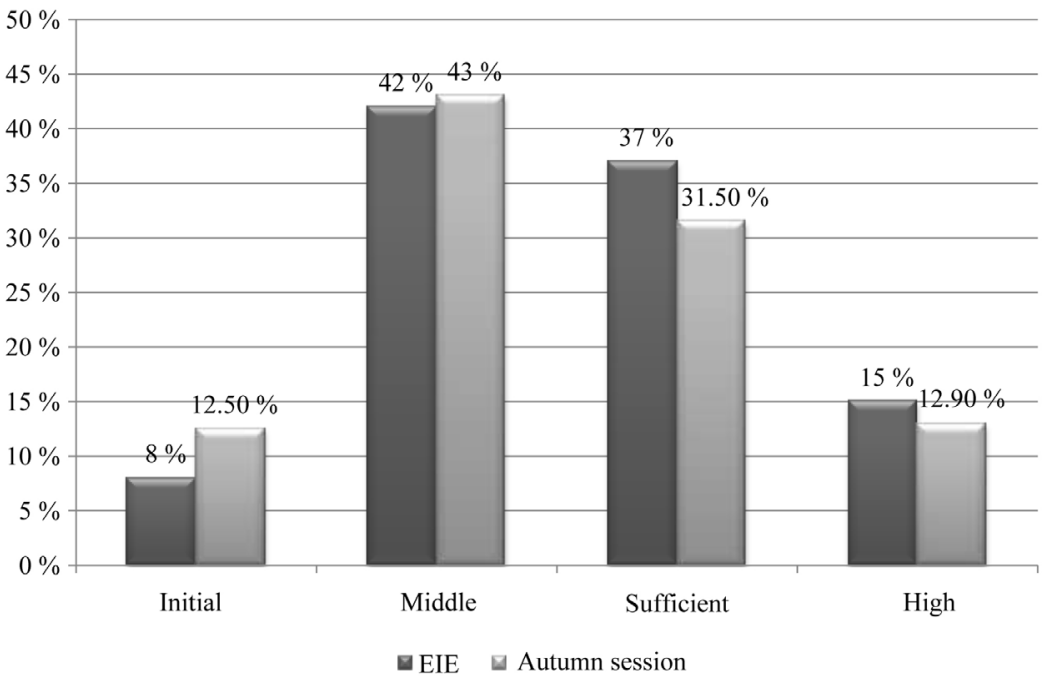

Eutumn session and the autumn session

$45 \%$

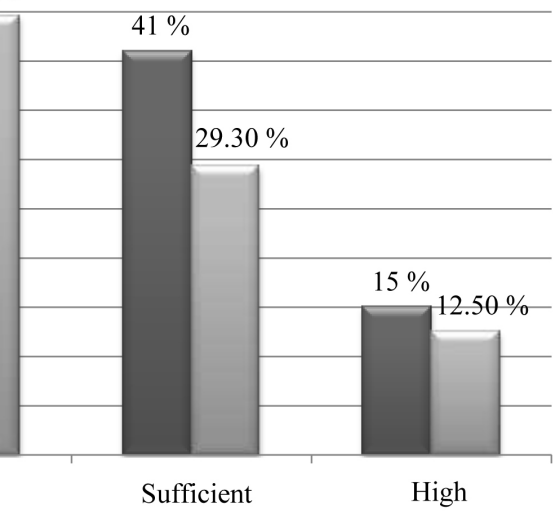

$\square$ EIE $\square$ Autumn session

and the autumn session

the humanities, it is almost impossible to describe a formula, or, moreover, a graph in text, words. The classroom whiteboard transforms into an interactive whiteboard. One way to attract students to work is to use an interactive whiteboard with student image editing permission. The teacher can depict, for example, elements of the problem, and the student - immediately add or correct at the invitation of the teacher, will be assessed live.

So, Fig. 3 shows a demo screen during an online lecture, a student solving a mathematical example (the student's name can be seen in the lower right corner).

Fig. 4 shows another example of communication with the student audience, when, at the suggestion of the teacher (black and green), the student adds a red line.

Another way is such an element of distance courses as a survey. Such an element is present in the Moodle environment, you can use third-party resources, for example, the National Agency for Quality Assurance in Higher Education uses the Mentimeter online resource.

A question for discussion is formulated (Fig. 5), and students (listeners) can directly switch to the element and express their opinion - by choosing one of the proposed options or in a completely free form. 

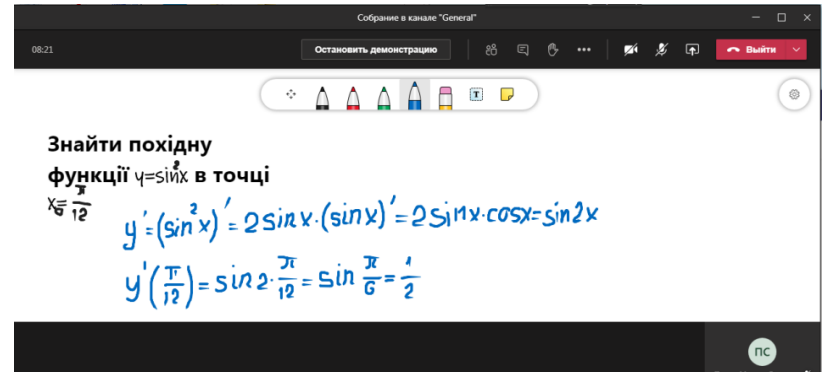

Fig. 3. Solution by a student to an example during an online lecture

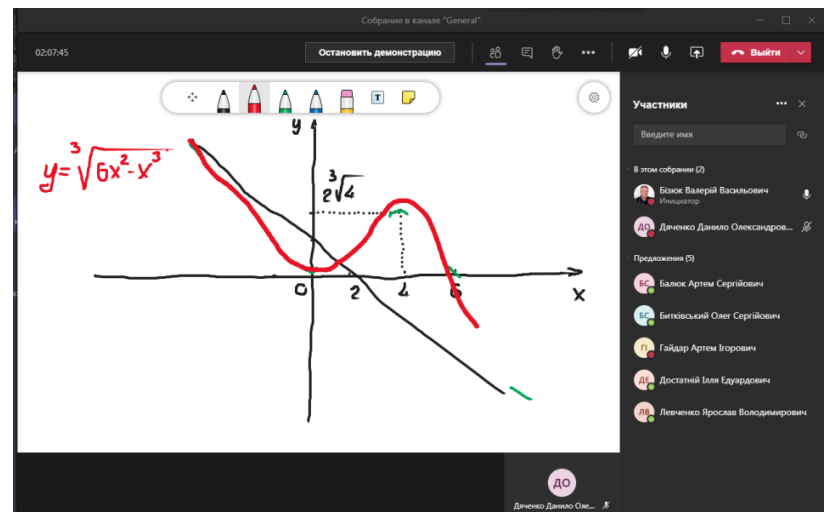

Fig. 4. An example of how a student can plot a function during an online lecture

\section{Mentimeter}

\begin{tabular}{l} 
На Вашу думку, з якими основними \\
викликами та проблемами зіштовхнувся \\
експерт протягом першого року акредитанії \\
за новою системою? Напишіть 3-4 слова. \\
\begin{tabular}{|l|}
\hline Enter o word \\
\hline Enter another word \\
\hline Enter another word \\
\hline Enter another word \\
\hline \\
\hline \multicolumn{1}{|c|}{ Hadicraти } \\
\hline
\end{tabular} \\
\hline
\end{tabular}

Fig. 5. An example of a request during an online seminar

The system immediately processes the data and presents it in a convenient graphical form (Fig. 6, 7). The teacher can comment on the result, and the students can independently assess the degree of correctness of their answer.

\section{Чи брали Ви участь у акредитаційних експертизах впродовж 2019-2020 року?}

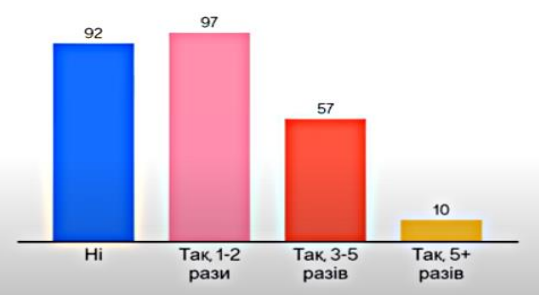

Fig. 6. Results of the survey during the online seminar in the form of bar graphs

\section{Зазначте, які цінності Національного агентства} близькими? Які з них Ви поділяєте?

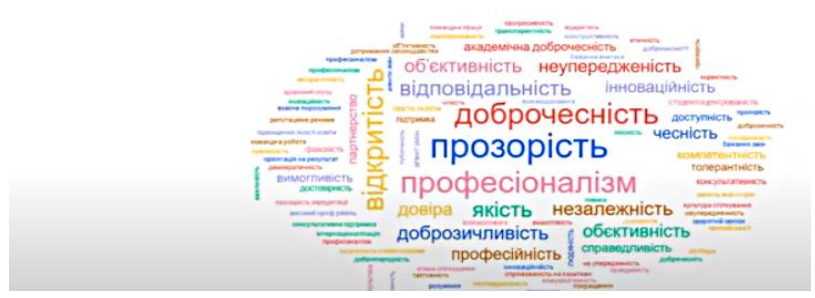

Fig. 7. Results of the survey during the online seminar in the form of a "word cloud»

It can be argued that due to feedback, the effectiveness of a practical lesson is higher than a lecture. Solving examples on an interactive whiteboard with student participation keeps the group active at all times. During the lecture, only discrete audio communication is possible. This speech is about the fact that the quality of teaching also depends on the quality of the equipment, programs used, various web servers, platforms, resources and social networks (Moodle, Zoom, Skype, Viber, Telegram and Messenger). It would be extremely useful to have a small screen on the monitor that would constantly reflect those present at the lecture. The experience of distance learning, especially during quarantine, prompts to comprehensively improve all components of the educational process. Distance learning will not replace classroom learning, but it has ample opportunity to get closer. Both forms have the right to exist, or rather coexistence in the direction of blended learning.

Distance learning must be perceived as an independent, independent, which has its own characteristics, not similar to other forms. That is, we do not always have to look for analogs, say, in a classroom form. If we are talking about a flexible assessment system, it is clear that a regular exam, written, or even more so oral, cannot be directly transferred to the distance form. And there is no need, because distance learning is able to develop its own forms of assessment. And not only in the educational process. Conducting Olympiads, the assessment of which gives additional points for admission to a higher educational institution. Student Olympiads, which assess the quality of a student's preparation and affect the rating of the university that he represents.

Distance education has now become a mass phenomenon all over the world, although the transition to such a «mass character» was in many cases forced. The resources of time and effort invested in the preparation and setup of distance courses have revealed new effective elements and opportunities of the educational process. The described in the article and other similar elements of distance courses are really only with modern computer tools, however, their use over time changes the structure of a training lesson, requires changes in roles in the «teacher-student» dialogue. Analysis of the production of distance education revealed significant differences from the traditional educational process of «classes and lessons», in particular the importance of further research in the areas of psychological and didactic aspects of distance learning. It is necessary to pay more attention to motivating students (pupils), to disseminate interactive teaching methods, to introduce elements of gamification, and the like. This also dictates 
the need to strengthen the appropriate training and retraining of teachers.

\section{Conclusions}

The study shows the need to improve cooperation between teacher and student in distance education as an important element of the quality of teaching. If it is still possible to control or correct this cooperation with a mixed form of education, or even in correspondence form, then with a strict quarantine, a number of problems have been identified in the implementation of distance education. This is natural, because it is impossible to replace classroom lessons, when the teacher owns the audience directly, with interactive ones without losses. It is possible to about the student's activity or passivity, the reproduction of mathematical or technical formulas, equations, graphs, and the like. Finally, feedback, the need for which is undeniable, as well as its impact on the quality of teaching. Along the way, note the large number of publications on the improvement of distance education in general, the development of distance courses in particular, which, however, do not single out as the main thesis, namely the quality of teaching the discipline. For example, the distance courses themselves include a full course of lectures, but sometimes the presentation of a lecture can be of high quality and more visual and accessible.

A comparative analysis of statistical data on the distribution of marks at the beginning and at the end of the distance learning course, which is given in the article, is used as a tool for an objective assessment of the level of feedback. This tool can also be interpreted as an indicator of teaching quality.

The research results will be useful in the process of teaching mathematical disciplines, developing innovative technologies, methods and not only teaching, but also paying special attention to the preparation, the previous organization of the educational process. It is quite interesting to compare the student's first results with his school achievements, as is done in comparison with the results of external independent assessment. By the way, such a comparison is possible in other disciplines as well. The quality of teaching individual disciplines in total gives the quality of training a specialist as a whole, which is the most important need of our time.

\section{References}

1. Kukharenko, V. M., Bondarenko, V. V. (2020). Ekstrene dystantsiine navchannia v Ukraini. Kharkiv: KP «Miska drukarnia», 409

2. Gritsuk, O. V., Gritsuk, Yu. V. (2018). Psychological aspects of using multimedia technologies in higher education institutions. Innovates and information technologies in education. Katowice: KST, 2, 157-171.
3. Hrytsuk, O. V. (2020). Dystantsiine navchannia ta problemy osobystosti v diadi «vykladach - student» v umovakh karantynu. Ekstrene dystantsiine navchannia v Ukraini. Kharkiv, 171-175.

4. 36th Distance Teaching and Learning Conference (2020). University of Wisconsin. Available at: https://dtlconference.wisc. edu/2020-archive

5. Tretya mezhdunarodnaya konferentsiya «eLearning Stakeholders and Researchers Summit» (eSTARS 2020) (2020). Available at: https://estars.hse.ru/

6. Biziuk, A. V., Tkachenko, V. P., Biziuk, V. V. (2020). Pro aktualnist zvorotnoho zviazku v dystantsiinii osviti. Polihrafichni, multymediini ta web-tekhnolohii. Kyiv, 177-179.

7. Malynyna, Y. A. (2014). Monitoring and feedback implementing in web-related resources 2.0. Sovremennye nauchnye issledovaniya $i$ innovatsii, 1. Available at: http://web.snauka.ru/ issues $/ 2014 / 01 / 30565$

8. Voronovska, L. P. (2018). Dystantsiinyi kurs u systemi vykladannia vyshchoi matematyky studentam, yaki navchaiutsia $v$ haluzi znan «budivnytstvo ta arkhitektura». Pedahohichni nauky, 2 (LXXXIV), 83-87.

9. Yarovaya, O., Yarovaya, L., Bogatskaya, E. (2020). Distance learning during coronavirus: problems and solutions. Innovative Technologies in Science and Education (ITSE-2020), 210, 18051. doi: http://doi.org/10.1051/e3sconf/202021018051

10. Bizyuk, A. V., Bizyuk, V. V. (2016). Osobennosti vnedreniya distantsionnogo obucheniya $\mathrm{v}$ mnogoprofilnykh vuzakh. iz opyta razrabotki distantsionnykh kursov vysshey matematiki. Informatsionnye sistemy i tekhnologii. Kharkiv, 189-190.

11. Moskalyuk, M., Moskalyuk, N. (2020). Use of remote technologies in the process of training future teachers of pedagogical higher education institutions. Physical and Mathematical Education 26 (4). doi: http://doi.org/10.31110/2413-1571-2020-026-4-014

12. Zhaksylykova, G. T. (2020). Effektivnaya obratnaya svyaz - zalog uspeshnosti distantsionnogo obucheniya. «Bilimdi el - Obrazovannaya strana». Available at: http://bilimdinews.kz/?p=103848

13. Ofitsiinyi zvit pro provedennia v 2019 rotsi zovnishnoho nezalezhnoho otsiniuvannia rezultativ navchannia, zdobutykh na osnovi povnoi zahalnoi serednoi osvity. Available at: https://testportal.gov.ua//wp-content/uploads/2019/08/ZVIT-ZNO_2019Tom_1.pdf

14. Ofitsiinyi zoit pro provedennia $v 2020$ rotsi zovnishnoho nezalezhnoho otsiniuvannia rezultativ navchannia, zdobutykh na osnovi povnoi zahalnoi serednoi osvity. Available at: https://testportal.gov.ua//wp-content/uploads/2020/09/ZVIT-ZNO 2020Tom_1_r.pdf

$\triangle$ Andrii Biziuk, PhD, Associate Professor, Department of Media Systems and Technologies, Kharkiv National University of Radio Electronics, Kharkiv, Ukraine, e-mail: andrii.biziuk@nure.ua, ORCID: http://orcid.org/0000-0001-9830-9206

Valerii Biziuk, PhD, Associate Professor, Department of Advanced Mathematics, O. M. Beketov National University of Urban Economy in Kharkiv, Kharkiv, Ukraine, ORCID: https://orcid.org/00000003-1235-9881

Tetiana Shakurova, Assistant, Department of Media Systems and Technologies, Kharkiv National University of Radio Electronics, Kharkiv, Ukraine, ORCID: https://orcid.org/0000-0002-7232-6611

$\triangle$ Corresponding author 